OPEN ACCESS

Approved by:

Frontiers in Immunology Editorial

Office,

Frontiers Media SA, Switzerland

*Correspondence:

Stephan Kloess

kloess.stephan@mh-hannover.de

Specialty section:

This article was submitted to Alloimmunity and Transplantation,

a section of the journal

Frontiers in Immunology

Received: 17 September 2018 Accepted: 18 September 2018 Published: 08 October 2018

Citation:

Kloess S, Ede Valverde da Silva A,

Oberschmidt O, Gardlowski T, Matthies N, Vyas M, Arseniev L, Heuser M, Pogge von Strandmann E and Köhl U (2018) Corrigendum:

Triplebody Mediates Increased

Anti-Leukemic Reactivity of IL-2

Activated Donor Natural Killer (NK)

Cells and Impairs Viability of Their

CD33-Expressing NK Subset.

Front. Immunol. 9:2326.

doi: 10.3389/fimmu.2018.02326

\section{Corrigendum: Triplebody Mediates Increased Anti-Leukemic Reactivity of IL-2 Activated Donor Natural Killer (NK) Cells and Impairs Viability of Their CD33-Expressing NK Subset}

\author{
Stephan Kloess ${ }^{1 *}$, Alessa Ede Valverde da Silva ${ }^{1}$, Olaf Oberschmidt ${ }^{1}$, Tanja Gardlowski ${ }^{1}$, \\ Nadine Matthies ${ }^{1}$, Maulik Vyas ${ }^{2}$, Lubomir Arseniev ${ }^{1}$, Michael Heuser ${ }^{3}$, \\ Elke Pogge von Strandmann ${ }^{4}$ and Ulrike Köhl ${ }^{1}$ \\ ${ }^{1}$ Institute for Cellular Therapeutics, IFB-Tx, Hannover Medical School (MHH), Hannover, Germany, ${ }^{2}$ Department I of Internal \\ Medicine, University Hospital of Cologne, Cologne, Germany, ${ }^{3}$ Department of Hematology, Hemostasis, Oncology, and Stem \\ Cell Transplantation, Hannover Medical School (MHH), Hannover, Germany, ${ }^{4}$ Experimental Tumor Research, Center for \\ Tumor Biology and Immunology, Philipps University Marburg, Marburg, Germany
}

Keywords: natural killer cells, natural killer group 2 member D, triplebodies, ULBP2, CD19, CD33, immunoligands, acute myeloid leukemia

\section{A Corrigendum on}

Triplebody Mediates Increased Anti-Leukemic Reactivity of IL-2 Activated Donor Natural Killer (NK) Cells and Impairs Viability of Their CD33-Expressing NK Subset by Kloess, S., Ede Valverde da Silva, A., Oberschmidt, O., Gardlowski, T., Matthies, N., Vyas, M., et al. Front. Immunol. (2017) 8:1100. doi: 10.3389/fimmu.2017.01100

In the original article, we neglected to include the following funding information:

This study was supported by a grant from the Deutsche Jose Carreras Leukämie-Stiftung to ES (DJCLS R 1408).

The authors apologize for this error and state that this does not change the scientific conclusions of the article in any way.

The original article has been updated.

Conflict of Interest Statement: The authors declare that the research was conducted in the absence of any commercial or financial relationships that could be construed as a potential conflict of interest.

Copyright (c) 2018 Kloess, Ede Valverde da Silva, Oberschmidt, Gardlowski, Matthies, Vyas, Arseniev, Heuser, Pogge von Strandmann and Köhl. This is an open-access article distributed under the terms of the Creative Commons Attribution License (CC BY). The use, distribution or reproduction in other forums is permitted, provided the original author(s) and the copyright owner(s) are credited and that the original publication in this journal is cited, in accordance with accepted academic practice. No use, distribution or reproduction is permitted which does not comply with these terms. 